\title{
INTRODUCING HIV AND AIDS EDUCATION INTO THE FIRST YEAR OF A PROBLEM- BASED LEARNING CURRICULUM: A TEMPLATE FOR HEALTH SCIENCE EDUCATION
}

\author{
Professor Michelle McLean \\ PhD, MEd \\ Department of Physiology (Histology), Nelson R Mandela School of Medicine, Faculty of Health Sciences, Univer- \\ sity of Natal \\ Corresponding author: mcleanm@ukzn.ac.za
}

\author{
Ms Linda Hiles \\ MA (Psychology) \\ Student Counselling Services, University of Natal Durban
}

Keywords: community; health science education; HIV and AIDS; medical students; problem-based learning

\begin{abstract}
The HIV and AIDS epidemic will continue to impact medically, socially and financially on sub-Saharan Africa. It is therefore imperative that health science students in Africa experience the reality of the impact of this virus on communities. This article describes an HIV and AIDS education programme instituted at a South African medical school in parallel with the first year of a problem-based learning (PBL) curriculum. In line with the PBL philosophy, the HIV and AIDS programme was largely experiential. Students interacted directly with HIV positive individuals, and through their educational workshops, with local communities. By means of small group sessions facilitated by trained community educators, students explored myths surrounding HIV and AIDS and engaged frankly with colleagues about sensitive issues such as having an HIV-infected family member. Although expensive in terms of human resources, the outcomes of this intervention exceeded the organisers' expectations, particularly in terms of students openly engaging with the reality of being HIV positive and the community organisation networks established. This type of experiential intervention with considerable community exposure has application to other health science curricula.
\end{abstract}

\section{OPSOMMING}

Die MIVIVIGS-epidemie sal voortduur om 'n mediese, sosiale en finansiële impak op Afrika, suid van die Sahara, te maak. Dit is dus noodsaaklik dat studente in die gesondheidswetenskappe in Afrika die impak wat die virus op plaaslike gemeenskappe maak eerstehands sal ervaar. Hierdie artikel beskryf die MIVIVIGS- ingrypingsprogram wat by ' $n$ Suid Afrikaanse mediese skool as deel van die eerste jaar van 'n probleemgebaseerde leerplan ingestel is. In ooreenstemming met die leerplanfilosofie is die MIVIVIGS program hoofsaaklik op ervaring gebaseer. Studente maak persoonlik met die plaaslike gemeenskap kontak deur middel van opvoedkundigewerkswinkels. Tydens kleingroepsessies met gekwalifiseerde opvoedkundiges as fasiliteerders, word mites rondom MIVIVIGS opgeklaar en sensitiewe inligting, soos om met ' $n$ MIV-positiewe gesinslid saam te leef, bespreek. Alhoewel die menslike hulpbroninsette hoog was, het die uitkomste van die program alle verwagtinge van die organiseerders oortref - veral ten opsigte van studente se verbintenis tot MIVIVIGS soos blyk uit die vestiging van netwerke in die gemeenskap. Hierdie tipe ervaringsleer, met aansienlike blootstelling aan die gemeenskap, is ook van belang vir ander leerplanne in die gesondheidswetenskappe. 


\section{INTRODUCTION}

\section{The HIV and AIDS epidemic}

HIV and AIDS present a unique challenge to society. No disease of recent times has produced more ethical dilemmas, been responsible for such destruction of family life or placed greater demands on health, education and social services than has this viral affliction and its complications. Globally, the HIV and AIDS epidemic has become manifest in Africa, with 25 million people living with HIV and AIDS in sub-Saharan Africa. In the region in 2003, an estimated three million people became newly infected with HIV and 2.2 million have already died of the disease (75\% of global AIDS deaths) (UNAIDS, 2004:3). South Africa has the greatest number of infected people, as well as one of the highest rates of infection in the world (Human Sciences Research Council, 2003:1). Already in 1996, almost half of child mortalities at the Chris Hani Baragwanath Hospital were reported to be HIV-related (Zwi, Pettifor, Soderland \& Meyers, 2000:227), while recent South African Government statistics show a $57 \%$ increase in the number of deaths between 1997 and 2002, attributed largely to AIDS (Sidley, 2005:438).

As many public hospital admissions are now HIV-related (Sidley, 2004:366), the HIV and AIDS epidemic has changed the face of medical practice in South and Southern Africa. The training and education of medical and other health science students must therefore take cognisance of this in striving to meet the evolving health care needs of the communities these students will serve. At King Edward Hospital, adjacent to the Nelson $R$ Mandela School of Medicine, which is used as one of the primary training sites for the University of KwaZuluNatal medical students, it is estimated that $60 \%$ of hospital mortalities are HIV and AIDS-related (Jinabhai \& Ramdas, 2003:2). Not only will students, as future health care practitioners, be faced with an increasing number of AIDS-related illnesses and deaths, but they will also be at risk of needle stick injury and will have to deal with the disillusionment and frustration of the lack of treatment recovery satisfaction. As part of their education and training, medical and other health professions students should therefore be made aware early in their studies of the impact of the HIV and AIDS epidemic on South African communities. In addition, as future community leaders, they should be able to com- municate effectively with those whom they will serve, as well as being able to devise and implement education programmes that contribute to a better life for the citizens of South Africa. Institutions that train health care practitioners therefore have a social responsibility to prepare their graduates to provide equity in and accessibility to health care, as articulated by the World Health Organisation's 'health-for-all' goal that has been endorsed by most nations (Boelen, 1999:S11).

HIV is an excellent example of a biopsychosocial phenomenon and as such, efforts to understand and deal with this disease should take cognisance of its multiple dimensions. This article describes and informs curriculum co-ordinators and developers of an HIV and AIDS education programme, set up largely by student counsellors and support staff, that was integrated into the first year of a problem-based learning (PBL) curriculum at the Nelson $\mathrm{R}$ Mandela School of Medicine (University of Natal, Durban, South Africa) in January 2001. This descriptive account provides a template that has application to health science education in general.

\section{PBL and the HIV and AIDS education pro- gramme at the Nelson R Mandela School of Medicine}

In 1997, the Nelson R Mandela School of Medicine Faculty Board resolved to replace the traditional discipline-based medical programme with a PBL curriculum, in line with the global trends in medical education reform. This reform was driven by two main forces: the global development of more student-centred curricula (for example, problem-, case- and community-based learning) and the need for the training and education of graduates who were able to deal with the changing health care needs of local communities (World Federation for Medical Education, 1994:S142).

PBL, first introduced at McMaster University (Canada) in the 1960s, has been implemented worldwide in many different educational settings (Camp, 1996:1). Despite the many variants of PBL, essential elements have remained. Typically, a small group of students (usually 8-10) collaboratively, with the aid of a tutor or a facilitator, work through a carefully constructed case or problem. In the first tutorial, students identify the observable phenomena (the triggers) that need to be explained. These are then discussed in the light of their prior knowl- 
edge, and hypotheses are generated to explain the phenomena. Learning goals (that is information needed to explain the hypotheses) are then generated by the group, and after a period of self- or group study, the students return to discuss their findings, which may result in a re-evaluation of earlier hypotheses (Norman \& Schmidt, 1992:557; Mennin \& Majoor; 2002:1-2; Wood, 2003:328). The strengths of PBL lie largely in its constructivist, self-directed approach to foster deep learning, the integration of basic sciences with clinical disciplines, its motivating effect on students and facilitators and the generic skills (for example, communication, respect for others, critical thinking) that it engenders in learners (Wood, 2003:331).

The 1999 Health Professions Council of South Africa's guidelines for the education and training of doctors in South Africa advocated the introduction of PBL to make teaching more practical, relevant and stimulating. Public health (for example, strategies for health promotion; defining environmental and social factors contributing to poor health, and evaluating the effectiveness of health interventions) should feature prominently in the curriculum such that future practitioners are sensitive to the unique needs of South African communities (HPCSA, 1999:9). In addition, clinical training needs to take place in different settings: primary health care facilities, hospitals and in communities (HPCSA, 1999:10).

A Curriculum Development Task Force was therefore established at the Nelson R Mandela School of Medicine to construct the blueprints and matrixes for all six-week integrated themes (six per year for Years 1 to 4) for the programme. Early exposure to real-life situations, taking cognisance of the many factors that impact of human health (for example, psychological, social, financial), was considered a key element of this new PBL curriculum (McLean, 2004:42). In January 2001, the Faculty introduced its PBL programme, Curriculum 2001, after more than 50 years of a traditional programme, with its primary objective to educate and train general practitioners who have the appropriate knowledge, skills and attitudes to service the health care needs of all South African communities. In the current context, HIV and AIDS form one of the core elements of Curriculum 2001.

While the emphasis of the PBL programme is on selfdirected learning, with the small group tutorials over- seen by a facilitator being one of the cornerstones, large group resource sessions (interactive lectures), provide students with some of the principles and concepts relating to each theme. Community involvement and patient contact is strongly emphasised from Year One in this new programme, in line with the recommendations of the HPCSA (1999).

\section{DETAILS OF THE HIV AND AIDS EDUCA- TION PROGRAMME}

\section{The organisers}

Cases in three of the six themes in the first-year of the mainstream PBL curriculum involve some aspect of HIV and AIDS. To complement first-year students' introduction to PBL and to medicine and to ensure that they become familiar with social, biological and medical aspects of HIV and AIDS, a task team was formed to design an HIV and AIDS education programme to run in parallel with Curriculum 2001. The team comprised a representative from the Curriculum Development Task Force, a specialist paediatrician in private practice who was also an honorary lecturer in the Department of Family Medicine, and two student counsellors (Hiles is one of the authors) at the Medical School. Student counsellor involvement was important as they were dealing with increasing numbers of students seeking personal support and counselling relating to HIV and AIDS.

The brief of this task team was to develop and implement an introductory HIV and AIDS programme which would pedagogically complement and run parallel with the mainstream PBL curriculum. The HIV and AIDS issue could then be addressed through the five years of medical study, either in cases or as electives. In order to comply with the PBL format, this programme needed to comprise small groups overseen by a facilitator, large group resource sessions, self-directed learning, and community or patient contact. In addition, the multi-faceted nature of HIV and AIDS, spanning many disciplines, both medical and social, had to be addressed, in line with the integrated nature of the PBL programme (hence the biopsychosocial focus of this education programme).

The primary objectives of the HIV and AIDS education programme were therefore directed towards address- 
ing the complexities of this epidemic such that students

- gain a comprehensive understanding of HIV and AIDS as a social, biological and medical problem;

- become aware of their own risks of infection; and

- $\quad$ are able to educate others in their communities about HIV and AIDS.

The learning outcomes of the programme thus included students

- $\quad$ acquiring an integrated knowledge of HIV and AIDS as a social, biological and a medical problem with psychological and financial impacts;

- developing skills in relation to communication about HIV and AIDS and related issues;

- becoming aware of current research and interventions regarding HIV and AIDS; and

- developing the appropriate attitudes which would enable them to work as team members, displaying respect for the community, especially towards people living with HIV and AIDS.

\section{HIV and AIDS education programme de- tails}

In line with the mainstream PBL curriculum, this HIV and AIDS education programme comprised large group resource sessions and small group tutorials, the latter overseen by a community facilitator, some of whom were HIV positive (Table 1). These small group tutorials provided students with an opportunity within a nonthreatening environment to learn facts about HIV and AIDS and to examine their own attitudes in this regard. It was hoped that together with direct engagement with HIV positive persons, this would contribute to a deeper understanding of the biopsychosocial complexities of HIV and AIDS (Table 1).

a) Large group resource sessions: These interactive lectures provided broad-based background information pertaining to HIV and AIDS and were undertaken by Faculty staff of international repute in the field of HIV and AIDS. These included a virologist and a paediatrician, and the scope included HIV and AIDS history, transmission statistics, HIV testing, clinical features, prevention, precautions and treatment (Table
1).

Perhaps the most influential aspect of this HIV and AIDS programme involved exposing students to an HIV positive woman, who, in the presence of 200 students, shared her story of discovering she was HIV positive just prior to her marriage and how she currently lives positively with the virus. Students were inspired by her openness and courage as well as the fact that she was healthy despite being infected for eight years. Ironically, this woman was white, which helped to dispel one of the myths that HIV and AIDS is a problem affecting Black Africans.

b) Small group tutorials and facilitators: Twenty HIV and AIDS educators from the community volunteered to serve as facilitators on the programme. As their skills and experience varied from working with people with AIDS and their families, to arranging HIV and AIDS workshops, a three-hour orientation workshop was organised to familiarise educators/facilitators with the aims and objectives of the Faculty's PBL curriculum to ensure uniformity of content within the tutorial sessions. This was essential, as the content covered in this programme would form part of the summative assessment of the mainstream curriculum. Facilitators were provided with a comprehensive resource manual covering the content of the HIV and AIDS education programme as well as the timetable, group lists and venues. Facilitators were assigned the same group of students for the duration of the HIV and AIDS programme ( \pm six months), to facilitate the development of trust and for continuity.

The small group tutorials were designed to address pertinent issues relating to HIV and AIDS, including some of the myths surrounding the disease and as well as first-hand experiences of living with HIV (Table 1). The first session, "Addressing the Myths", encouraged students freely question and explore aspects of HIV and AIDS which they needed to deal with from a personal perspective. The session included exercises to assist them in getting to know and trust one another as well as clarifying frequently asked questions about HIV and AIDS, sexuality, gender and sexual decisionmaking.

Attitudes and perceptions were the focus of another small group tutorial, giving students the opportunity to 
Table 1: Details of HIV and AIDS education programme: Overview of training of educators and firstyear medical students

\begin{tabular}{|c|c|c|c|}
\hline Format & Details & Summary & Presenters \\
\hline Workshop (3 h) & Educators' orientation & $\begin{array}{l}\text { HIV and AIDS programme (format } \\
\text { and content); Introduction to PBL, } \\
\text { including facilitating small group } \\
\text { sessions }\end{array}$ & Organising task team \\
\hline $\begin{array}{l}\text { Large Group Resource } \\
\text { Session ( } 2 \text { h) }\end{array}$ & $\begin{array}{l}\text { Student orientation and } \\
\text { introduction }\end{array}$ & $\begin{array}{l}\text { Introduction to the HIV and AIDS } \\
\text { education programme (content; } \\
\text { format, etc.) } \\
\text { Questions and answers }\end{array}$ & Organising task team \\
\hline $\begin{array}{l}\text { Large Group Resource } \\
\text { Session (2h) }\end{array}$ & $\begin{array}{l}\text { Introduction to HIV and } \\
\text { AIDS }\end{array}$ & $\begin{array}{l}\text { History, transmission of HIV, } \\
\text { statistics, testing, clinical features, } \\
\text { treatment, prevention, precautions }\end{array}$ & $\begin{array}{l}\text { Expert virologist and } \\
\text { expert paediatrician }\end{array}$ \\
\hline Small Group Tutorial 1 (2h) & Myths and realities & $\begin{array}{l}\text { Introduction to HIV and AIDS } \\
\text { Questions about HIV and AIDS }\end{array}$ & $\begin{array}{l}\text { Facilitators }+ \text { groups of } \\
9-10 \text { students }\end{array}$ \\
\hline Small Group Tutorial 2 (2h) & $\begin{array}{l}\text { Developing educational } \\
\text { presentations }\end{array}$ & $\begin{array}{l}\text { Designing a presentation: target } \\
\text { audience, audio-visual aids, etc. }\end{array}$ & $\begin{array}{l}\text { Facilitators }+ \text { groups of } \\
9-10 \text { students }\end{array}$ \\
\hline Small Group Tutorial 3 (2h) & $\begin{array}{l}\text { Perceptions and } \\
\text { precautions regarding } \\
\text { HIV and AIDS }\end{array}$ & $\begin{array}{l}\text { Safer sex-abstinence, use of } \\
\text { condoms } \\
\text { Needle stick injuries }\end{array}$ & $\begin{array}{l}\text { Facilitators }+ \text { groups of } \\
9-10 \text { students }\end{array}$ \\
\hline $\begin{array}{l}\text { Large Group Resource } \\
\text { Session (1h) }\end{array}$ & $\begin{array}{l}\text { Living positively with HIV } \\
\text { and AIDS }\end{array}$ & $\begin{array}{l}\text { HIV positive speaker discusses her } \\
\text { experiences of being HIV positive }\end{array}$ & Educator \\
\hline Small Group Tutorial 4 (1h) & $\begin{array}{l}\text { Living positively with HIV } \\
\text { and AIDS }\end{array}$ & Discussion of speaker's experiences & $\begin{array}{l}\text { Facilitators }+ \text { groups of } \\
9-10 \text { students }\end{array}$ \\
\hline Assignment (1h) & Educating the community & $\begin{array}{l}\text { Discussion of community education } \\
\text { project }\end{array}$ & Organisers \\
\hline $\begin{array}{l}\text { Large Group Resource } \\
\text { Session (1h) }\end{array}$ & Evaluation & $\begin{array}{l}\text { Feedback on assignments; } \\
\text { evaluation of programme }\end{array}$ & Organisers \\
\hline
\end{tabular}

explore their attitudes and prejudices which could potentially serve as barriers to learning about and protecting themselves from HIV and AIDS in a personal and professional capacity (Table 1). It is important that as future doctors and health care workers they are aware of their attitudes towards people with HIV and AIDS to avoid discrimination and to increase their sensitivity towards the circumstances of affected individuals.

\section{c) Additional resources: A WebCT HIV and AIDS course} was set up, with resources such as appropriate websites and the pre- and post-test counselling schedules. Relevant books and pamphlets were placed on reserve in the library. d) Community education component: A frequent query during the orientation presentation was why, when the general public is provided with information regarding HIV infection, was the infection rate still increasing? It was decided that a community-based experience might address this issue. Pairs of students were tasked with designing an HIV and AIDS awareness/education presentation for their communities. In the session on preparing educational material, students were provided with scenarios (for example, "Prepare an introductory HIV and AIDS talk for 100 high school learners between 15 and 18 years of age"). They then had to prepare lesson plans to assist them with their community talks which were discussed by the organisers to ensure the appropriateness of language, as well as details of the in- 
tended audience (for example, age, gender, size of group). Each group was provided with a detailed assessment rubric to assist with the assignment. The basic skills required for the assignment were addressed in the second small group tutorial which was held before the vacation, enabling the students to run workshops during the vacation close to their homes and in their mother tongue, if they so chose. Many visited schools, often those they had attended as learners.

e) Evaluation: As the aim of this article is to describe details of the HIV and AIDS education programme, evaluation is only briefly mentioned. Evaluation included:

- assessing students' knowledge acquisition through a pre- and a post-test (True/False format);

- gauging student response to the various activities (small groups tutorials; community involvement) by means of questionnaires; and

- canvassing HIV educators regarding the value of the facilitator training.

Unsolicited responses (for example, telephone calls and letters to the organisers) from headmasters or educators following the community intervention could also be considered as qualitative evaluation.

\section{IMPLEMENTATION, APPLICATION AND SUSTAINABILITY OF THE HIV AND AIDS EDUCATION PROGRAMME}

\section{General comments}

From student comments in the evaluation, the overall objectives of the programme appeared to have been met. They had been able to freely ask questions and discuss sensitive issues within their small groups. They also had to reflect on their views of HIV and AIDS by discussing issues such as confidentiality, doctor/patient rights, risks and precautions, and they had an opportunity to share the knowledge and insights they gained with their communities. The small group discussions were enjoyed as they provided an opportunity to unravel HIV and AIDS issues and for everyone to offer an opinion. Students commented that appropriate knowledge leads to maturity in decision-making, which directly relates to personal empowerment. The major criticism from students, however, was that the programme was too short, and they requested that, in the future, each tutorial be longer.

On reflection, the outcomes of this HIV and AIDS programme far exceeded the expectations of the task team. In meeting the original objectives of the task team, there were additional unanticipated benefits. These included empowering students with valuable life skills through open discussions relating to sexual behaviour and decision-making, increasing student openness regarding personal experiences of living with HIV and AIDS, establishing a valuable community network and empowering 'support' staff (especially student counsellors) in terms of developing their expertise in the philosophy of PBL, which would be invaluable in dealings with students presenting with academic difficulties in Curriculum 2001.

\section{Response from the communities}

With the community-based project, it is estimated that almost 2000 individuals from various social settings, but importantly including rural communities and schools, were exposed to education component of the HIV and AIDS programme. Perhaps the most valuable aspect of this outreach aspect was the fact that much of it was peer education, as most students chose to visit schools. There were several invitations from principals, educators and learners for the students to return, either to provide additional information or to make presentations to other classes so that most of the school would be exposed to the information.

\section{Potential sustainability shortcomings}

While it would appear that the HIV and AIDS education programme encountered no difficulties, this would not be true. There are issues that may persist beyond implementation. Just as PBL is considered to be labourintensive in terms of providing competent facilitators for the small group sessions (Mennin \& Majoor, 2002:7), so too was this programme. In order to accommodate the 200 students into manageable groups, 20 volunteer community educators were trained as facilitators. While they were not remunerated for their time, funding had to be sought for transport costs as most earned very little in their current posts. Furthermore, the same individuals may not be available on an annual basis and so facilitator training may have to take place each year. Involving institutional departments such as Fam- 
ily Medicine, Community Development or Rural Health may assist with continuity.

As with mainstream PBL, the same HIV and AIDS education programme should be available for each incoming cohort of students such that the foundations can be added to in a spiral fashion as they progress through their studies. For this reason, blueprints and matrixes need to be developed for the programme so that in the event of members of the task team leaving the institution (which has already happened), there is some degree of continuity. This would certainly contribute to the sustainability of such a programme.

\section{CONCLUSIONS}

Notwithstanding some of the difficulties encountered along the way, there can be no doubt of the value of exposing young students to the stark reality of HIV and AIDS, both in their personal capacity and as future practitioners on developing the appropriate attitudes and behaviour towards patients. As many students engaged first-hand with HIV and AIDS in the real world, it became a personal issue for those who may have had family members infected or were themselves HIV positive. As HIV and AIDS will continue to impact on the resources of the South African health care system for many decades (Human Sciences Research Council, 2003:56), this early introduction to the real world experiences of the epidemic should provide students with insight into some of the dilemmas in the current and future practice of medicine. This HIV and AIDS education programme should also have made students aware that since clinical solutions may not always exist and a cure may take years to develop, social and psychological issues assume greater importance. The authors are of the opinion that such an education programme could be incorporated into health science curricula, with appropriate contextually and locally relevant modifications.

\section{ACKNOWLEDGEMENTS}

The authors would like to thank the other members of the task team: Pretha Shah (student counsellor), Dr Shakira Cassim (Paediatrician and honorary lecturer in Family Medicine) and Dorothy Appalasamy (Medical Education Development). Without the voluntary support of the community educators, this HIV and AIDS programme would not have been possible.

\section{REFERENCES}

BOELEN, C 1999: Adapting health care institutions and medical schools to societies' needs. Academic Medicine, 74:S11-S20. CAMP, G 1996: Problem-based learning. A paradigm shift or a passing fad? Medical Education Online, 1:1-6. HEALTH PROFESSIONS COUNCIL OF SOUTHAFRICA (HPCSA) 1999: The education and training of doctors in South Africa. Guidelines by the Medical and Dental Professional Board. Pretoria: HPCSA.

HUMAN SCIENCES RESEARCH COUNCIL 2003: The impact of HIV and AIDS on the health sector. Pretoria: HSRC, MEDUNSA, MRC. JINABHAI, CC \& RAMDAS, PD 2003: Managing the epidemiology and demographic challenges facing hospitals in KwaZulu-Natal, South Africa. $11^{\text {th }}$ Conference on Health Promoting Hospitals $(\mathrm{HPH})$, Florence, Italy, May 18-20. http:/www.univie.ac.at/hph/ florences $2002 / \mathrm{htm} /$ details/virtual-proceedings/ Jinabhai_epidemiological-challenges.ppt.

MCLEAN, M 2004: Sometimes we do get it right! Early clinical contact is a rewarding experience. Education for Health, 17:4252.

MENNIN, S \& MAJOOR, S 2002: Problem-based learning. A Position Paper of the Network Towards Unity for Health. http:// www.the-networktufh.org/publications_resources/ positioncontent.asp?id=6\&t=Position+Papers

NORMAN, G \& SCHMIDT, HG 1992: The psychological basis of problem-based learning: A review of the evidence. Academic Medicine, 67:557-565.

SIDLEY, P 2004: South African health services must strengthen infection control measures. British Medical Journal, 328:366. SIDLEY, P 2005: Sharp rise in deaths in South Africa is largely due to AIDS. British Medical Journal, 330:438-439.

UNAIDS 2004: Executive summary: Report on the global AIDS epidemic. Geneva: UNAIDS.

WOOD, DF 2003: ABC of learning and teaching in medicine. Problem-based learning. British Medical Journal, 326:328-330. WORLD FEDERATION FOR MEDICAL EDUCATION 1994: World summit on medical education. The changing medical profession. Recommendations. Medical Education, 28:140S-149S.

ZWI C; PETTIFOR, J; SODERLUND, N \& MEYERS, T 2000: HIV infection and in-hospital mortality at an academic hospital in South Africa. Archives of Diseases in Childhood, 83:227-230. 


\title{
THE EFFECT OF FORMAL EXPOSURE TO DEVELOPMENTAL CARE PRINCIPLES ON THE IMPLEMENTATION OF DEVELOPMENTAL CARE POSITIONING AND HANDLING OF PRETERM INFANTS BY NEONATAL NURSES
}

\author{
Rachell Louw \\ BSocSc (UOFS), MCur (UP), Diploma Educ (UP) \\ Registered nurse (general, psychiatric, community nursing), Midwife, Neonatal nurse, Nurse educator \\ M Cur (Advanced Neonatal Nursing) student, University of Pretoria
}

\section{Carin Maree}

BCur (UP), Diploma Paediatric Nursing, BACur (UNISA), MCur (RAU), Diploma Neonatal Nursing (UP)

Registered nurse (general, psychiatric, community nursing), Midwife, Paediatric nurse, Nurse educator and administrator, Neonatal nurse

Lecturer, Department of Nursing Science, University of Pretoria

Corresponding author: cmaree@postillion.up.ac.za

Keywords: developmental care; developmental care positioning; developmental care handling; preterm infants; training exposure

\begin{abstract}
The preterm infant requires developmental care that is designed to minimise the stress that the infant experiences within the neonatal intensive care unit (NICU). The aim of the study was to determine the effect of formal exposure to developmental care principles on the implementation of developmental care positioning and handling of the preterm infant by neonatal nurses. The first objective of the study was to compile an accurate scale for measuring the implementation of these principles with respect to the handling and positioning of the infant. Secondly, the study aimed at determining changes in the implementation of developmental care principles within a selected NICU after neonatal nurses were formally exposed to developmental care training. A quasi-experimental research design and a one-group pre-test-post-test approach were followed, and the Wilcoxon matched-pair signed-rank tests were used to examine the changes. Results were statistically significant and indicated improvement with respect to the developmental care components that were measured. The recommendation was that developmental care principles be integrated into formal neonatal courses. Follow-up studies should be conducted to determine the reliability of the instrument for possible inclusion in routine assessment of the quality of the implementation of developmental care in the NICU.
\end{abstract}

\section{OPSOMMING}

Die vroeggebore baba benodig ontwikkelingsorg wat ontwerp is om die stres wat die baba in die neonataleintensiewesorgeenheid ervaar, te minimaliseer. Die doel van die studie was om die effek van formele blootstelling aan ontwikkelingsorgbeginsels op die implementering van ontwikkelingsorgposisionering en -hantering van die vroeggebore baba deur neonatale verpleegkundiges te bepaal. Die eerste doelwit van die studie was om 'n akkurate metingskaal daar te stel vir die meting van die implementering van hierdie beginsels ten opsigte van die hantering en posisionering van die baba. Die tweede doelwit was om die veranderinge in die implementering van ontwikkelingsorgbeginsels binne 'n geselekteerde neonatalesorgeenheid te bepaal nadat neonatale verpleegkundiges formeel aan ontwikkelingsorgopleiding blootgestel is. ' $n$ Kwasi-eksperimentele ontwerp en 'n een-groep pretoetsposttoetsbenadering is gevolg, en die Wicoxon vergelykbare toetse van betekende range is gebruik om die veranderinge te meet. Die resultate was statisties beduidend en het verbetering aangedui ten opsigte van die komponente van ontwikkelingsorg wat gemeet is. Die aanbeveling was dat ontwikkelingsorgbeginsels geïntegreer word in formele neonatale kursusse. Opvolgstudies moet gedoen word om die betroubaarheid van die instrument vir 
moontlike insluiting in roetine-assessering van die kwaliteit van die implementering van ontwikkelingsorg in die neonatalesorgeenheid te bepaal.

\section{INTRODUCTION, RATIONALE AND LIT- ERATURE REVIEW}

A greater knowledge base and improved technological interventions had a profound effect on the survival rates of preterm infants who previously would have died (Lynch, 1991:79; Taquino \& Lockridge, 1999:64). These babies have left the ideal, safe environment for neurological development provided by the womb and are subjected to loud noises, bright lights and frequent physical assaults to facilitate medical treatment in the neonatal intensive care unit (NICU). Time and longitudinal research indicated that the unfriendly environment of the NICU was not only unpleasant for tiny babies, but also enhanced their vulnerability to a variety of adverse neurodevelopment outcomes (Buehler, Als, Duffy, McAnulty \& Liederman, 1995:930).

The primary goal of health care professionals caring for a critically ill individual is to provide the necessary therapeutic interventions, thereby maximising healthcare potential and minimising complications or morbidity (Lynch, 1991:78). It has been suggested that injury to the preterm developing brain resulting from the stressful intensive care environment is responsible for a portion of the overall morbidity suffered by these preterm infants (Young, 2000:preface). Buehler et al. (1995:923) suggest that premature experiences of the extra-uterine environment at a time of rapid brain development altered brain differentiation and influenced later development. As these consequences could be prevented, the challenge confronting the professional nurse in the NICU was not only to assure survival, but also to support the infant's developmental progression (Als, Duffy \& McAnulty, 1996:21). Thus, the provision of care in the NICU should be aimed at establishing a physical and social environment that was supportive of the infant's rapidly developing nervous system.

The premature newborn requires individualised developmental care (Als, Lawhorn, Duffy, McAnulty, GibesGrossman \& Blickman, 1994:853-4). Symington and Pinelli (2002:1) describe developmental care as a broad category of interventions designed to minimise the stress caused by the NICU environment for the infant.
According to these authors, interventions may include "... one or more elements such as control of external stimuli (vestibular, auditory, visual, tactile), clustering of nursery care activities, and positioning or swaddling of the preterm infant". Taquino and Lockridge (1999:64) describe developmental care as individualised, behaviourally guided practice that bases interactions and interventions on the infant's behavioural and physiological cues, and strives to reduce external stressors by modifying the environment.

Developmental care positioning is an important component of the developmental care of a preterm infant. It entails providing containment, supporting the infant's hands in midline, flexion of the body, arms, legs and feet, and hip adduction (Lynch, 1991:81). Handling of the preterm infant also plays an important role in the implementation of developmental care, and includes gentle touch, skin-to-skin contact and slow positional changes (Jorgensen, 2000:1-4).

Since neonatal nurses are the primary caregivers in the NICU and it is the caregiver's responsibility to enhance each infant's strengths, neonatal nurses are in a key position to influence the environment of the developing neonate (Als, 1998:138; Young, 2000:3). Young (2000:3) explains this as follows: "To fulfil their role, neonatal nurses must take responsibility for identifying and reducing stimuli in the preterm infant's environment which may damage the developing nervous system." Lynch (1991:79) agrees, stating that neonatal nurses are in a key position to modify potential risks and prevent injuries associated with therapeutic interventions. To ensure that preterm infants derive maximum benefit from developmental care principles, these principles have to be implemented thoroughly.

Being a neonatal nurse, the researcher was concerned about the quality of developmental care practised in the NICU selected for this study. None of the neonatal nurses in the selected NICU had any formal exposure to developmental care training that included attendance of any seminar, conference, or workshop where these principles were explained. However, all the neonatal nurses working at the selected NICU had informal ex- 
posure to the implementation of developmental care. They obtained knowledge about this approach through observance.

The successful implementation of the positioning and handling of preterm infants according to developmental care principles is the sole responsibility of the individual neonatal nurse who is taking care of a particular infant. The successful implementation of most of the other aspects of developmental care such as environmental manipulation (light and noise reduction, or a positive smell) is dependent on the cooperation between all role players within the NICU.

The positioning and handling of the preterm infant according to developmental care principles by the neonatal intensive care professional nurse (neonatal nurse) were the focus of this study, because the individual neonatal nurse's implementation of these principles could be observed and assessed.

The hypothesis was that formal exposure to the principles and practice of this new approach to infant care would result in improved implementation of developmental care positioning and handling of preterm infants by neonatal nurses, and the null hypothesis was that such exposure would produce no improvement. The study aimed at determining the effect of formal exposure to developmental care principles on the implementation of these principles by neonatal nurses, with specific reference to the positioning and handling of preterm infants.

\section{RESEARCH METHODOLOGY}

\section{First objective: Development of the instru- ment}

The first objective of the study was to compile an accurate scale for measuring the implementation of developmental care positioning and handling of preterm infants since validated evaluation sheets could not be found in the literature. Information obtained from evidence-based literature on developmental care positioning and handling was incorporated into items on a scale through processes of inductive and deductive reasoning (Burns \& Grove, 1987:25-6; Polit \& Hungler, 1993:330).
During construction of the instrument, items were refined and organised in an appropriate sequence and format. Rating the scales and matching the instrument items with the test statistics were part of the process. The instrument's structural validity was established with the assistance of statisticians, while eight experts on developmental care of preterm infants were requested to confirm the content validity. The experts represented different disciplines, but were chosen on the grounds that they were recognised as experts in the developmental care approach regarding preterm infants by professionals working in the field. Seven of the eight experts responded and were in agreement that the content of the instrument was valid. Having confirmation from statistical and subject expertise on the validity of the instrument with respect to both its construction and content maximised the possibility of having an instrument that could be used for accurate measurement of the effect of the independent variable (Davis, 1992:194). The instrument is presented as Table 1.

\section{Second objective: Determining the effect of formal exposure to developmental care principles on infant care by neonatal nurses}

During this phase of the study, a quasi-experimental design and an intra-subject or one-group pre-test-posttest approach were used to investigate the causal relationship between formal exposure of neonatal nurses to developmental care principles (independent variable) and the implementation of developmental care positioning and handling of preterm infants by these nurses (dependent variable) (De Vos, Strydom, Fouche \& Delport, 2002:144; Polit \& Hungler, 1993:18-9,136-41).

The research population $(\mathrm{N}=11)$ consisted of a single group of neonatal nurses who were working at the NICU of the hospital where the study was conducted. Since all the neonatal nurses working at the NICU were evaluated, the population constituted a non-probability convenience sample (Polit \& Hungler, 1993:176). All the neonatal nurses in the NICU gave written informed consent to participate in the study. Over a three-week period, all these nurses were evaluated on their positioning and handling of preterm infants according to the developmental care principles. These evaluations (pretesting and post-testing) took place while the partici- 


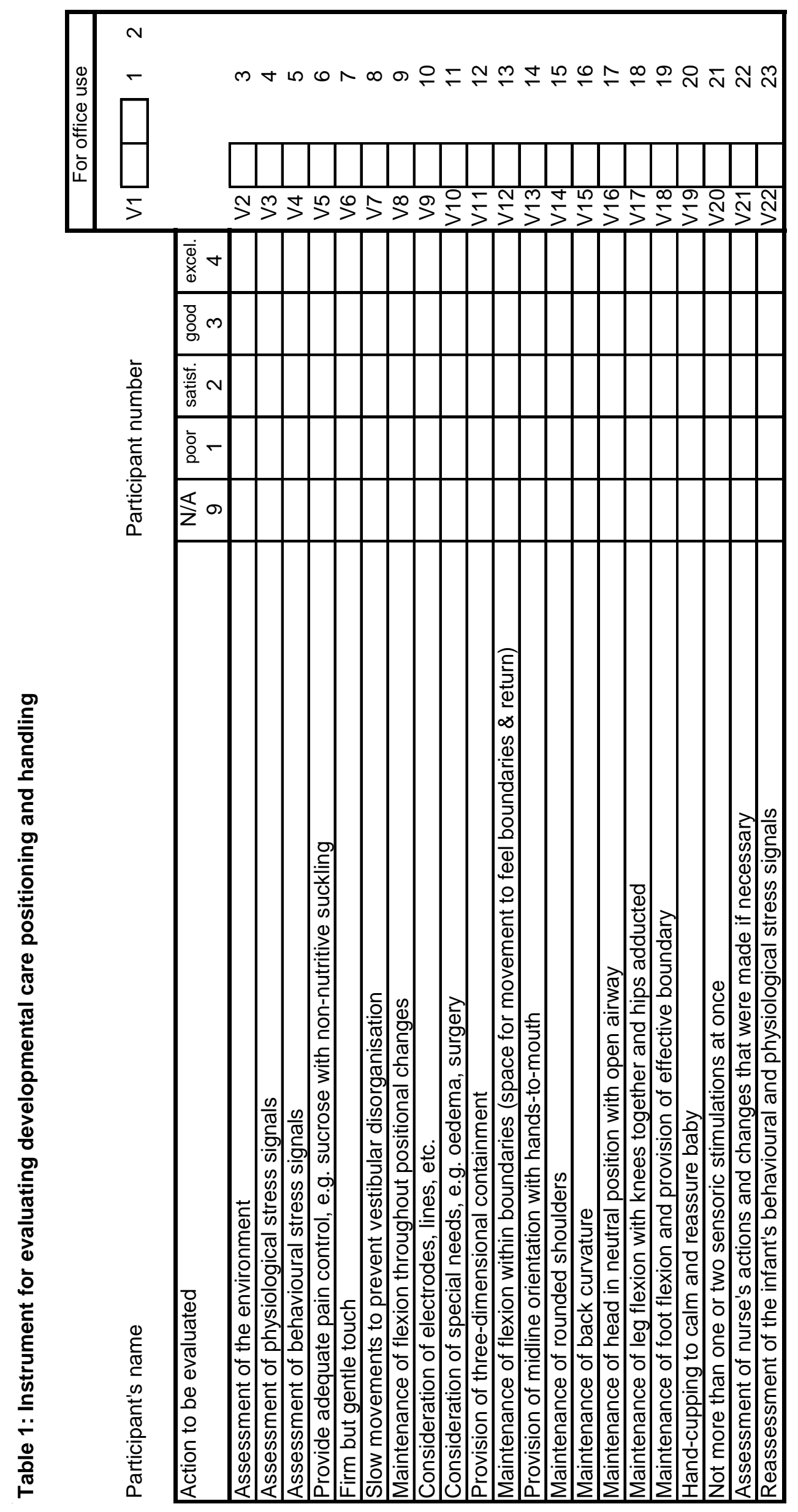


pant and the researcher were working together and the participant was busy with routine care of a preterm infant.

After completion of the pretest evaluations, all participants attended a workshop on developmental care principles and hands-on training presented by an expert (formal exposure). Thus, attendance of a workshop on the principles of developmental care that included hands-on training represented the independent variable. Within the next four weeks after participants had attended the workshop, the post-test evaluations were done, using the same instrument on the same subjects by the same person (researcher). It should be emphasised that this study was aimed at evaluating the effect of formal exposure to developmental care principles on the positioning and handling of preterm infants by neonatal nurses, and that it was never the intention to evaluate the nurses' ability to implement these principles. For this reason and to prevent the Hawthorne effect, neonatal nurses were unaware of the exact date on which they would be re-evaluated (although they did know that post-test evaluations would be done).

\section{Validity and reliability}

Measures taken to enhance the validity and reliability of the study included the steps taken to obtain a valid and reliable instrument for accurate measurement. The researcher collected all the data herself to enhance consistency in measurement, and the independent variable was introduced only after all the data of the pretests were collected. The collection of the post-test measurements took place after the independent variable was introduced, but the participants did not know the exact dates of the re-evaluations so that a true reflection of changes effected by the independent variable could be obtained.

\section{Ethical considerations}

The researcher obtained institutional and individual informed consent prior to the study, as well as ethical approval from the Ethics Committee of the Faculty of Health Sciences within the University of Pretoria. Participant confidentiality was upheld throughout the study. No harm was done to any preterm infant, as developmental care was the right of all neonatal patients. The expectation was that the consequences of the study would imply improvement in the implementation of developmental care principles to the benefit of preterm babies.

\section{Data analysis}

Once all the evaluations were done, the data were analysed by means of the software package, the Statistical Analysis System (SAS). The components of the dependent variable (implementation of developmental care positioning and handling) were identified and divided into four groups, namely:

- assessment of the environment and infant before handling of the infant;

- $\quad$ assessment of the neonatal nurse's handling of the preterm infant;

- assessment of the neonatal nurse's positioning of the preterm infant; and

- reassessment of the preterm infant and the neonatal nurse's response.

The components of each group are set out in Table 2.

The Wilcoxon matched-pair signed-rank tests were used to examine the changes that occurred in the pre-testpost-test evaluations (matched pairs) (Burns \& Grove, 1987:524-5; Polit \& Hungler, 1993: 438-42).

\section{Results}

\section{Group 1: Assessment before handling of the preterm infant}

The t-value of the results of Group 1 as a whole was 0.002 that was statistically significant, and indicated improvement in the assessment of the environment and the preterm infant by the neonatal nurse before handling of the infant. See Figure 1.

\section{Group 2: Assessment of the neonatal nurse's handling of the preterm infant}

Being 0.001 , the t-value of the results of Group 2 as a whole was also statistically significant. It indicated improvement in the handling of the preterm infant by the neonatal nurse. See Figure 2.

\section{Group 3: Assessment of the neonatal nurse's positioning of the preterm infant}

The neonatal nurses' positioning of preterm infants 
Table 2: Components of the dependent variable

\begin{tabular}{|c|c|}
\hline GROUP & $\begin{array}{l}\text { COMPONENTS OF DEVELOPMENTAL CARE } \\
\text { HANDLING AND POSITIONING }\end{array}$ \\
\hline $\begin{array}{l}\text { 1. Assessment before } \\
\text { handling the preterm } \\
\text { infant }\end{array}$ & $\begin{array}{l}\text { a. Assessment of the environment } \\
\text { b. Consideration of electrodes, lines, etc. } \\
\text { c. Assessment of physiological stress signals } \\
\text { d. Assessment of behavioural stress signals }\end{array}$ \\
\hline $\begin{array}{l}\text { 2. Assessment of the } \\
\text { neonatal nurse's handling } \\
\text { of the preterm infant }\end{array}$ & $\begin{array}{l}\text { a. Firm, but gentle touch } \\
\text { b. Hand-cupping to calm and reassure the infant } \\
\text { c. Not more than two sensory stimulations at once } \\
\text { d. Slow movements to prevent vestibular disorganisation } \\
\text { e. Consideration of special needs, e.g. oedema and surgery } \\
\text { f. Maintenance of flexion throughout positional changes } \\
\text { g. Provision of adequate pain control, e.g. sucrose with non-nutritive sucking }\end{array}$ \\
\hline $\begin{array}{l}\text { 3. Assessment of the } \\
\text { neonatal nurse's } \\
\text { positioning of the preterm } \\
\text { infant }\end{array}$ & $\begin{array}{l}\text { a. Provision of three-dimensional containment } \\
\text { b. Maintenance of flexion within boundaries, with space for movement for the infant } \\
\text { c. Maintenance of leg flexion with knees together and hips adducted } \\
\text { d. Maintenance of foot flexion and provision of effective boundaries } \\
\text { e. Provision of midline orientation with hands to mouth } \\
\text { f. Maintenance of back curvature } \\
\text { g. Maintenance of rounded shoulders } \\
\text { h. Maintenance of the head in a neutral position with an open airway }\end{array}$ \\
\hline $\begin{array}{l}\text { 4. Reassessment of the } \\
\text { preterm infant and the } \\
\text { neonatal nurse's } \\
\text { response }\end{array}$ & $\begin{array}{l}\text { a. Assessment of the nurse's actions and changes that were made if necessary } \\
\text { b. Reassessment of the infant's behavioural and physiological stress signals }\end{array}$ \\
\hline
\end{tabular}

showed improvement, as indicated by the statistically significant t-value (0.001) of the results of the components of Group 3.

\section{Group 4: Reassessment of the preterm infant and the neonatal nurse's response} The t-value (0.002) of the results regarding the reassessment of the preterm infant and the response of the neonatal nurse was statistically significant, and demonstrated improvement.
On the whole, the results of the study showed a statistically significant improvement in the neonatal nurses' handling and positioning of preterm infants after formal exposure to developmental care principles and handson experience in the format of a workshop. The hypothesis was therefore found to be true, and the null hypothesis was rejected. Thus, formal exposure of neonatal nurses to developmental care principles resulted in a significant improvement in the implementation of developmental care positioning and handling of the preterm infant. 
Figure 1: Assessment before handling a preterm infant

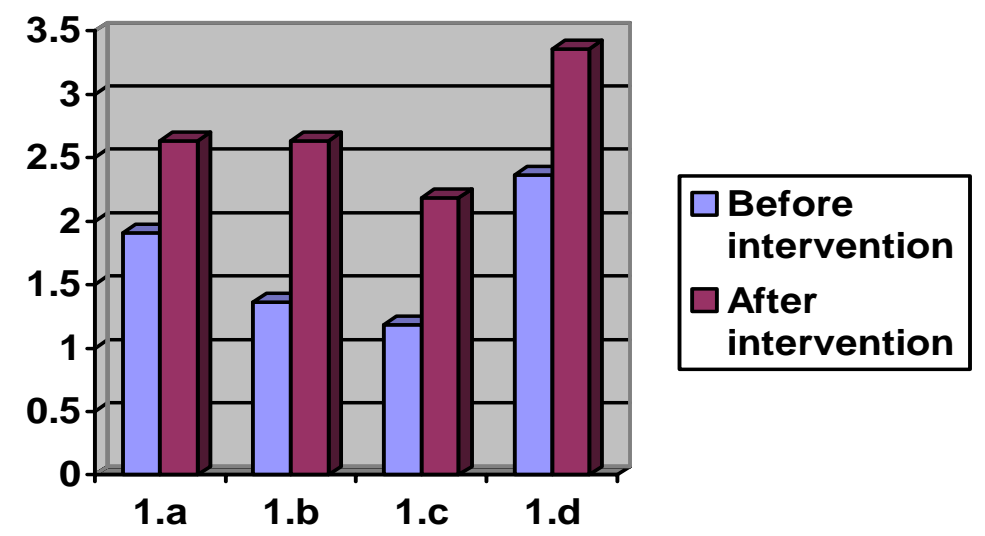

1.a Assessment of the environment

1.b Consideration of electrodes, lines, etc.

1.c Assessment of physiological stress signals

1.d Assessment of behavioural stress signals

Figure 2: Assessment of the neonatal nurse's handling of the preterm infant

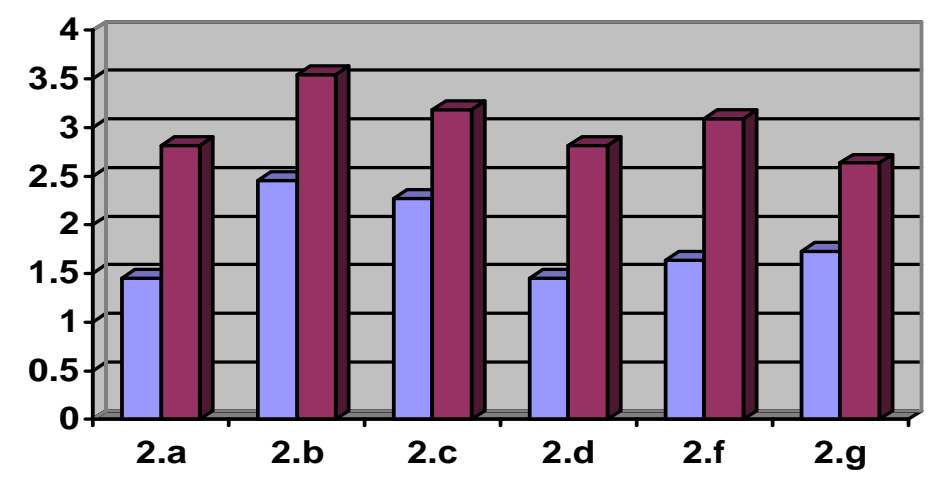

2.a Firm but gentle touch

2.b Hand-cupping to calm and reassure the infant

2.c Not more than one or two sensory stimulations at the same time

2.d Slow movements to prevent vestibular disorganisation

2.f Maintenance of flexion throughout positional changes

2.g Provision of adequate pain control, e.g. sucrose with non-nutritive suckling

CONCLUSIONS AND RECOMMENDATIONS

The purpose of the study was to make an inference that the formal exposure of neonatal nurses to developmental care principles and hands-on training was truly influencing the implementation of developmental care positioning and handling of preterm infants (De Vos et al. 2002:144; Polit \& Hungler, 1993:156). As the results indicated that formal exposure of neonatal nurses to developmental care principles improved their implementation of developmental care positioning and handling of preterm infants, the hypothesis of the study could be accepted, and the null hypothesis be rejected.

Although this was a small study, results hinted at the 
Figure 3: Assessment of the neonatal nurse's positioning of the preterm infant

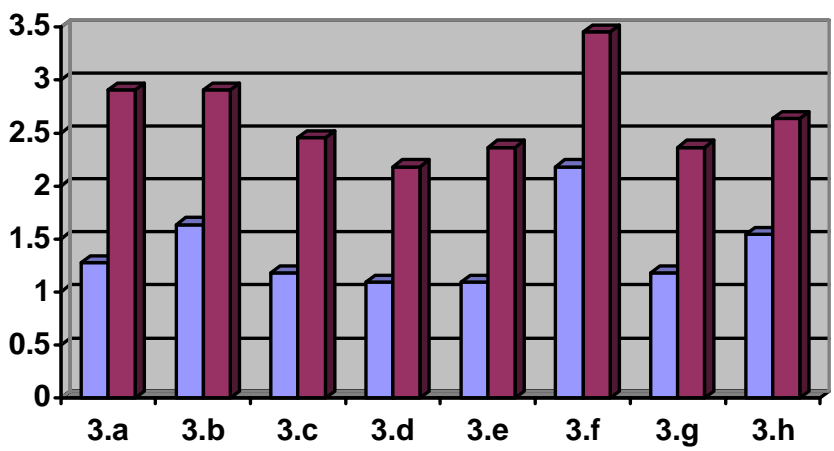

$\square$ Before intervention
$\square$ After intervention

3.a Provision of three-dimensional containment

3.b Maintenance of flexion within boundaries, with space for movement for the infant to feel boundaries and return

3.c Maintenance of leg flexion with knees together and hips adducted

3.d Maintenance of foot flexion and provision of effective boundary

3.e Provision of midline orientation with hands-to-mouth

3.f Maintenance of back curvature

3.g Maintenance of rounded shoulders

3.h Maintenance of head in neutral position with open airway

Figure 4: Reassessment of the preterm infant and the neonatal nurse's actions

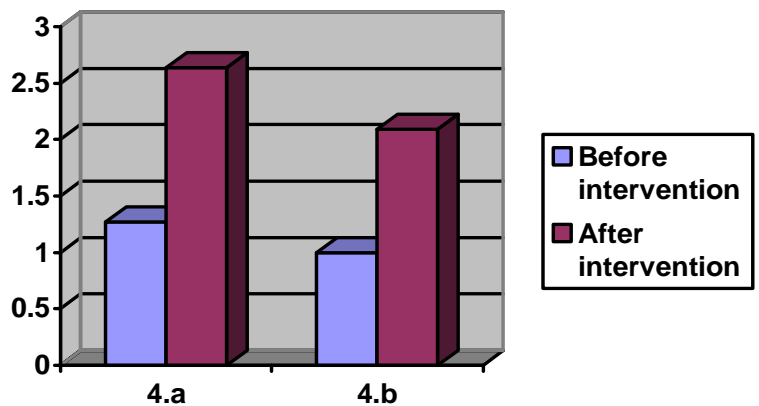

4.a Assessment of the nurse's actions and changes that were made if necessary

4.b Reassessment of the infant's behavioural and physiological stress signals

benefits of formal exposure of nurses to the principles of a new concept. It seems that formal introduction of a new concept by means of a workshop or formal courses, covering core literature, advantages and disadvantages, ethical and legal responsibilities, as well as hands-on training, has an advantage over informal exposure.

Thus, the following recommendations are made:

- Developmental care principles should be integrated into formal neonatal courses.

- As unit managers lead by example, also with respect to the acquisition of new knowledge and skills and professional-ethical conduct, they should be urged to take an active interest in the new approach to infant care, especially since this approach is evidence-based and justified.

- However, as acquisition of the necessary knowledge and skills does not guarantee implementation of developmental care principles, the recommendation is made that unit managers instil the right values and 
attitudes toward this approach in neonatal nurses.

- Further research on the phenomenon, as well as the sustainability of improved implementation after formal exposure, is recommended.

- Furthermore, follow-up studies should be conducted to determine the reliability of the instrument for possible inclusion in routine assessment of the quality of the implementation of developmental care positioning and handling of preterm infants in neonatal intensive care settings.

The contribution of this study has been the improved implementation of developmental care positioning and handling of preterm infants in the specific context in which the study was conducted, to the benefit of the preterm infants.

\section{LIST OF REFERENCES}

ALS, H 1998: Developmental care in the newborn intensive care unit. Current Opinion in Pediatrics, 10:138-142.

ALS, H; DUFFY, FH \& MCANULTY, GB 1996: Effectiveness of individualized neurodevelopmental care in the newborn intensive care unit (NICU). Acta Paediatrics Supplement, 416:21-30. ALS, H; LAWHORN, G; DUFFY, FH; MCANULTY, GB; GIBESGROSSMAN, R \& BLICKMAN, JG 1994: Individualized developmental care for the very low-birth-weight preterm infant: Medical and neurofunctional effects. Journal of the American Medical Association, 272(11):853-858.

BUEHLER, DM; ALS, H; DUFFY, FH; MCANULTY, GB \& LIEDERMAN, J 1995: Effectiveness of individualized developmental care for low-risk preterm infants: Behavioural and electrophysiologic evidence. Paediatrics, 96(5):923-932.

BURNS, N \& GROVE, SK 1987: The practice of nursing research: Conduct, critique and utilization. Philadelphia: Saunders.

DAVIS, LL 1992: Instrument review: Getting the most from a panel of experts. Applied Nursing Research, 5:194-197.

DE VOS, AS; STRYDOM, H; FOUCHé, CB \& DELPORT, CSL 2002: Research at grass roots: For the social sciences and human service professions; $2^{\text {nd }}$ edition. Pretoria: Van Schaik.

JORGENSON, KM 2000: Developmental care of the preterm infant: A concise overview [Online]; $2^{\text {nd }}$ edition. Available: www.childmed.com. Accessed: 2001.08.30.

LYNCH, ME 1991: latrogenic hazards, adverse occurrences, and complications involving NICU nursing practice. Journal of Perinatal and Neonatal Nursing, 5(3):78-86.
POLIT, DF \& HUNGLER, BP 1993: Essentials of nursing research: Methods, appraisal, and utilization; $3^{\text {rd }}$ edition. Philadelphia: Lippincott.

SYMINGTON, A\& PINELLI, J 2002: Developmental care for promoting development and preventing morbidity in preterm infants (Cochrane Review). (In: The Cochrane Library, vol. 1 [CD-ROM]. Oxford: Update Software: 1-37).

TAQUINO, LT \& LOCKRIDGE, T 1999: Caring for critically ill infants: Strategies to promote physiological stability and improve developmental outcomes. Critical Care Nurse, 19(6):64-78.

YOUNG, J 2000: Developmental care of the premature baby. London: Bailliere Tindall. 